\title{
Connection between tree functional traits and environmental parameters in an archipelago of montane forests surrounded by rupestrian grasslands ${ }^{\text {in }}$
}

\author{
Marcel S. Coelho ${ }^{a, b, *}$, Priscila P. Carlos ${ }^{a}$, Victor D. Pinto ${ }^{a}$, Alline Meireles ${ }^{a}$, \\ Daniel Negreiros ${ }^{\mathrm{a}, \mathrm{c}}$, Leonor Patrícia Cerdeira Morellato ${ }^{\mathrm{b}}, \mathrm{G}$. Wilson Fernandes ${ }^{\mathrm{a}}$ \\ a Ecologia Evolutiva Er Biodiversidade/DBG, ICB/Universidade Federal de Minas Gerais, 30161970 Belo Horizonte, MG, Brazil \\ b UNESP Universidade Estadual Paulista, Instituto de Biociências, Departamento de Botânica, Laboratório de Fenologia, Rio Claro, São Paulo, 13506-900, \\ Brazil \\ c Centro Universitário UNA, Instituto de Ciências Biológicas e Saúde. Rua Guajajaras, 175, 30180-100, Belo Horizonte, MG, Brazil
}

\section{A R T I C L E I N F O}

\section{Article history:}

Received 22 December 2016

Received in revised form 4 April 2017

Accepted 5 April 2017

Edited by Fernando A O Silveira

Available online 10 April 2017

\section{Keywords:}

Atlantic rain forest

Ecotones

Environmental filters

Espinhaço range

Forest natural fragments

Functional traits

\begin{abstract}
A B S T R A C T
Forest islands are unique habitats standing out across mountains dominated by rupestrian grassland in southeastern Brazil. In this work we evaluated the relationship between the plant species functional traits (number of ecoregions in which a species occurs, potential height, mean height, mean basal area, mean leaf area) and ecological variables (leaf damage from chewing herbivores, the number of individuals) with environmental parameters (physical and chemical properties of the soil, canopy cover) of the tree communities in an archipelago of montane forest islands immersed in rupestrian grasslands. We found a strong connection between the traits of tree species and environmental parameters; habitats associated with high soil fertility and canopy cover (leaf area index) harbored species with high structural values (i.e., height and basal area), broad distribution among Brazilian ecoregions, high rates of leaf damage from chewing insects and fewer individuals. Habitats with low soil fertility and canopy cover values harbored species with low structural values, restricted geographic distribution and low rates of leaf damage by chewing insects. Although physical parameters play an important role in the establishment of forest islands, our results point to chemical indicators of soil fertility as a relevant environmental promoter, influencing the composition and structure of island tree communities. The impact of local habitat parameters on the tree species functional traits showed that habitat heterogeneity is essential in structuring tree communities in this natural archipelago of forest islands. We advocate that understanding the connection between habitat parameters and species functional traits can help to predict the ecological consequences of anthropogenic or natural impacts to those forests, supporting the development of effective conservation strategies.
\end{abstract}

(c) 2017 Elsevier GmbH. All rights reserved.

\section{Introduction}

Ecological relationships, whether antagonistic (e.g., predation, herbivory, competition) or mutualistic (e.g., pollination, seed dispersal), are important mechanisms for the maintenance of communities and can influence the distribution of species along environmental gradients (Gotelli and McCabe, 2002; Englund et al., 2009; Kraft et al., 2015). However, both regional (e.g., landscape

\footnotetext{
This article is part of a special issue entitled Plant life in campo rupestre: new lessons from an ancient biodiversity hotspot published at the journal FLORA 238C.

* Corresponding author at: UNESP Universidade Estadual Paulista, Instituto de Biociências, Departamento de Botânica, Laboratório de Fenologia, Rio Claro, São Paulo, 13506-900, Brazil.

E-mail address: marcel.s.coelho@gmail.com (M.S. Coelho).
}

effects) and local environmental parameters may play a key role in the success of species establishment (Ackerly and Cornwell, 2007; Jamoneau et al., 2011), and therefore, environmental parameters could act as a filter or promoter, determining the establishment of some species (Southwood, 1988; Grime and Pierce, 2012).

Among local environmental parameters that are directly related to species distribution in tropical forests, soil properties, canopy cover, temperature, seasonality and rainfall stand out as filters or promoters to establishment (Lebrija-Trejos et al., 2010; Paine et al., 2011; Lasky et al., 2013). The response of each species to such environmental properties is dependent on their phenotypic characteristics expressed by genes under the influence of the environment. Functional traits can be defined as any measurable trait at the individual level that is directly or indirectly related to reproductive performance (fitness) (e.g., growth, fecundity, survival) (Violle et al., 2007). The relationship between plant functional traits and 
habitat properties can unveil drivers behind species distributions along environmental gradients. This might advance the understanding of ecosystem functions and represents a tool for predicting how changes in the properties of the habitat can influence species distribution and establishment (Lavorel and Garnier, 2002; de Bello et al., 2010).

The association between forest and grassland vegetation has fueled the interest of the scientific community, especially understanding how drivers control the natural boundaries between such very distinct ecosystems (Safford, 2007; Bond, 2008, 2010; Rehm and Feeley, 2015). There are many factors that can influence the expansion or contraction of forest edges on natural grasslands, among them climate (Harsh and Bader, 2011; Halladay et al., 2012 Halladay et al., 2012), seed dispersion and germination, and seedling establishment (Dullinger et al., 2004; Cierjacks et al., 2007; Körner, 2012; Rehm and Feeley, 2013), fire (Bond and Keeley, 2005; Veldman et al., 2015), soil patches (Coelho et al., 2016), as well as anthropogenic disturbances (Kolbek and Alves, 2008) stand out. Most studies on the subject have focused on high mountains, between 3000 and $4000 \mathrm{~m}$ a.s.l., where forests are replaced by grasslands with increasing altitude (Körner, 1998; Jobbágy and Jackson, 2000; Körner and Paulsen, 2004). However, tropical mountains of lower altitudes (between 1000 and $3000 \mathrm{~m}$ a.s.l) or tropical snow-free mountains (Streher et al., 2017) exhibited naturally fragmented landscapes formed by forest islands immersed in a grassland matrix, characterizing true forest archipelagos. In such landscape, forests and grasslands coexist at the same altitudinal levels, indicating that additional factors such as soil physical and chemical parameters might be responsible for the distribution of tree species (Coelho et al., 2016). Thus, natural forest islands on mountaintops are excellent models for testing hypotheses involving the connection between local environmental properties and the functional traits of tree community. Understanding how environmental parameters of the habitat are related to the species composition of forest islands will improve knowledge regarding the genesis, maintenance and ecological connection between naturally fragmented forests and the grasslands in which they are immersed.

The Espinhaço Mountain Range (Cadeia do Espinhaço) is the largest mountain chain in Brazil and, especially in its southern portion, separates two biodiversity hotspots, the Cerrado and the Atlantic Forest (Silveira et al., 2016). The more humid eastern slopes of the mountains are covered by semi-deciduous forests associated with the Atlantic Forest domain, while the drier western slopes are covered by physiognomies associated with the Cerrado domain - predominantly campo rupestre (Silveira et al., 2016) hereafter rupestrian grasslands. Part of the humidity of the eastern slope of the mountains reaches the transitional zones located near the mountaintops and advances over rupestrian grasslands located at higher altitudes (Coelho et al., 2016, 2018; Streher et al., 2017). When the moist conditions are associated with soil patches with chemical and physical parameters different from surrounding rupestrian grasslands soil, these areas of environmental suitability favor the establishment of tree-dominated physiognomies or forests islands, locally called capões de mata (Coelho et al., 2016 and references therein). Tree species are dispersed to these humid mountaintops predominantly by animals, via gallery forests from the eastern slope, forming archipelagos of forest islands (Coelho et al., 2018; Pereira et al., 2017). Since forest islands are not able to expand due to soil and micro environmental conditions, they increase the landscape complexity of the rupestrian grasslands (Coelho et al., 2016). However, understanding how these forest islands connect with local environmental conditions and what factors are determinant for their establishment and maintenance is a sine qua non requirement to unveil how forest islands integrate into the contrasting grassland matrix in which they are immersed. The soils of the rupestrian grasslands have acted as major environmen- tal filter leading to a predominance of the stress-tolerant strategy in plant communities what points out to the existence of very specific conditions promoting the establishment of wet forest islands (Negreiros et al., 2014).

We investigate therefore the functional traits and associated environmental parameters of forest islands from Espinhaço range. We expect a strong connection between the functional traits and ecological variables of the tree community - number of ecoregions in which a species occurs, potential height, mean height, mean basal area, mean leaf area, foliar damage caused by chewing folivores, number of individuals - and the habitat parameters relevant to the establishment and maintenance of forest islands - physical and chemical soil properties, and canopy cover. Thus, the following hypotheses were tested: 1) leaf damage, leaf area, number of ecoregions, average height, potential height and average basal area respond positively to canopy cover and soil fertility, and 2) species abundance respond negatively to canopy cover and soil fertility.

\section{Materials and methods}

\subsection{Study area}

This study was carried out in Serra do Cipó in the southern portion of the Cadeia do Espinhaço, in the central region of the state of Minas Gerais, southeastern Brazil. According to the Köppen classification system, the climate of Serra do Cipó is type Cwb with well-marked seasonality of dry winters and humid summers (Alvares et al., 2013). The average rainfall in the region ranges from 1300 to $1600 \mathrm{~mm}$ and is concentrated between November and January (Madeira and Fernandes, 1999; Fernandes et al., 2016). The vegetation of Serra do Cipó is predominantly influenced by components of two important ecoregions in Brazil, the Cerrado domain to the west and the Atlantic Forest domain to the east. The soils associated with grasslands environments are generally acidic, with high levels of aluminum saturation and low levels of base saturation (Schaefer et al., 2016; Silveira et al., 2016). The Cerrado is represented predominantly by rupestrian grasslands located above $900 \mathrm{~m}$, which covers more than half of the area of Serra do Cipó and hosts most of the diversity and endemism recorded for the region (Madeira et al., 2008).

The forest islands of the Espinhaço Range are forest formations of edaphic-climatic nature; that is, their maintenance is dependent on specific climate and soil parameters (see Coelho et al., 2016 for a review). They are immersed in a rupestrian grassland matrix and located above $1200 \mathrm{~m}$ a.s.l. (Fig. 1). Because they are close to the mountaintops, they are within the zone of influence of the tropical Atlantic mass arising from the eastern slope - more humid and within the Atlantic Forest domain - which loses strength on the western slope - drier and in the Cerrado domain (Coelho et al., 2016). Thus, these forest islands provide an important ecological service of protecting regions of springs and headwaters of the tributaries of important Brazilian rivers (Coelho et al., 2018). Seven forest islands were selected for this study (Fig. 2) based upon level of conservation, size and accessibility (Fig. 2).

\subsection{Sampling design}

A $20 \times 50-\mathrm{m}$ plot was placed in the center of each island and subdivided into 10 sub-plots of $10 \times 10 \mathrm{~m}$ for a total of seven plots and 70 subplots for all the seven islands selected. All individual trees, with diameter at breast height (DBH) greater than $2.5 \mathrm{~cm}$, in each plot were marked and numbered with aluminum tags. Information regarding the number of each individual, plot and subplot of their location were included with each tag. For each tagged tree, the height was measured with a Haglof Electronic Clinometer, 


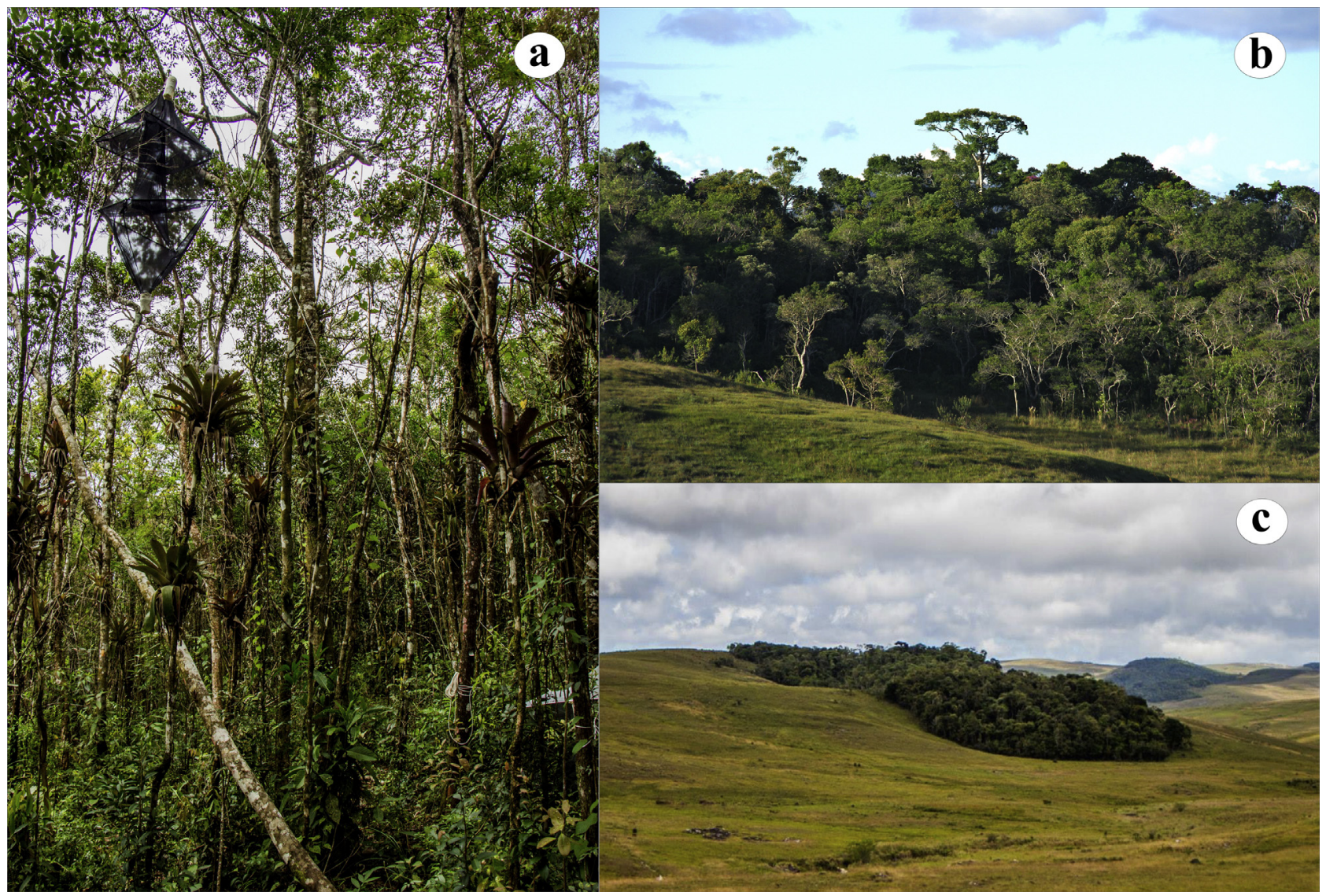

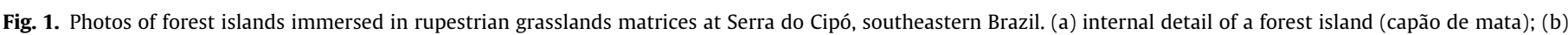

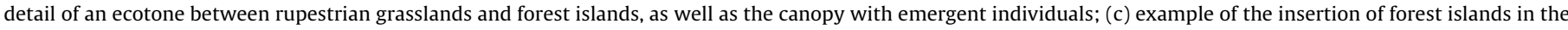
rupestrian grasslands matrix.

since it provides more precise and accurate measurements, and the DBH (Diameter at Breast High) was measured with a tape measure (Mueller-Dombois and Elemberg, 1974).

\subsection{Collection of botanical material}

Field campaigns took place from December 2012 to February 2013 , the peak of the rainy season. Botanical material of each individual was collected with the help of a 9-stage pruning shears, each measuring $1.5 \mathrm{~m}$. After identification, the specimens were deposited in the herbarium of the Departamento de BotânicaUFMG (BHCB). The classification of the species followed the system proposed by Angiosperm Phylogeny Group IV (APG IV, 2016).

Thirty mature and completely expanded leaves were collected from the apical third of each individual ( $n=2008$ sampled). The leaves were pressed in the field and transported to the laboratory. After drying, all leaves were scanned using a desktop scanner at 300dpi resolution. Leaf damage caused by chewing insects was estimated for each leaf with the help of the program Image Tool (University of Texas Health Science Center at San Antonio, San Antonio, TX, USA). All images were calibrated to $0.1 \mathrm{~mm}$ before measurements and the program allowed no resolution errors greater than $1 \%$. The average leaf damage of the 30 leaves of each individual was used as replicates.

\subsection{Soil collection}

A composite soil sample (of approximately $500 \mathrm{~g}$ ) was collected in each subplot, which represented a valid estimate of the average of the nutritional levels of five simple samples of $100 \mathrm{~g}$ (modified from Binkley and Vitousek, 1989), for a total of 10 composite samples per plot and 70 soil samples for the entire study. Sampling was done according to the procedures described by Dick et al. (1996). The $\mathrm{pH}$ in water was measured using the proportion of $1: 2.5(\mathrm{v} / \mathrm{v})$ of soil:solution. The exchangeable cations $\mathrm{Ca}^{2+}, \mathrm{Mg}^{2+}$ and $\mathrm{Al}^{3+}$ were extracted by a solution of $1 \mathrm{~mol} / \mathrm{L} \mathrm{KCl}$ and the contents of $\mathrm{Ca}^{2+}$ and $\mathrm{Mg}^{2+}$ were determined by titration with $0.01 \mathrm{~mol} / \mathrm{L}$ EDTA and the contents of $\mathrm{Al}^{3+}$ by titration with $0.025 \mathrm{~mol} / \mathrm{L}$ $\mathrm{NaOH}$, according to EMBRAPA (1999). The elements P and $\mathrm{K}$ were extracted by Mehlich 1 solution. The potential acidity $(\mathrm{H}+\mathrm{Al})$ was extracted with a $0.5 \mathrm{~mol} / \mathrm{L}$ calcium acetate solution at $\mathrm{pH} 7.0$ and determined by alkalimetric titration of the extract (EMBRAPA, 1999). Aluminum saturation ( $\mathrm{m})$ and base saturation (V), were calculated with the equations $\mathrm{m}=100 . \mathrm{Al}^{3+} /\left(\mathrm{K}+\mathrm{Ca}^{2+}+\mathrm{Mg}^{2+}+\mathrm{Al}^{3+}\right)$; and $\mathrm{V}=100 .\left(\mathrm{K}+\mathrm{Ca}^{2+}+\mathrm{Mg}^{2+}\right) /\left(\mathrm{K}+\mathrm{Ca}^{2+}+\mathrm{Mg}^{2+}+\mathrm{H}+\mathrm{Al}\right)$, respectively (Alvarez et al., 1999).

\subsection{Canopy cover sampling by means of hemispheric photos}

In January 2013 - at the peak of the wet season - a hemispheric photo was taken at the center of each subplot for a total of 10 hemispheric photos per plot and a total of 70 photos for the entire study. The photos were taken with the camera facing north and positioned $1.50 \mathrm{~m}$ above the ground with the aid of a tripod. The photos were taken early in the morning or late in the afternoon with a Nikon CoolPix 5400 digital camera with a FCE9 fisheye lens. The photos were evaluated using the software Gap light Analyzer 2.0, which was calibrated by altitude and coordinates (Frazer et al., 1999). Hemispherical images have a wide coverage $\left(180^{\circ}\right)$ with light openings between the angles of 0 to $75^{\circ}$, simultaneously. Using the Gap 


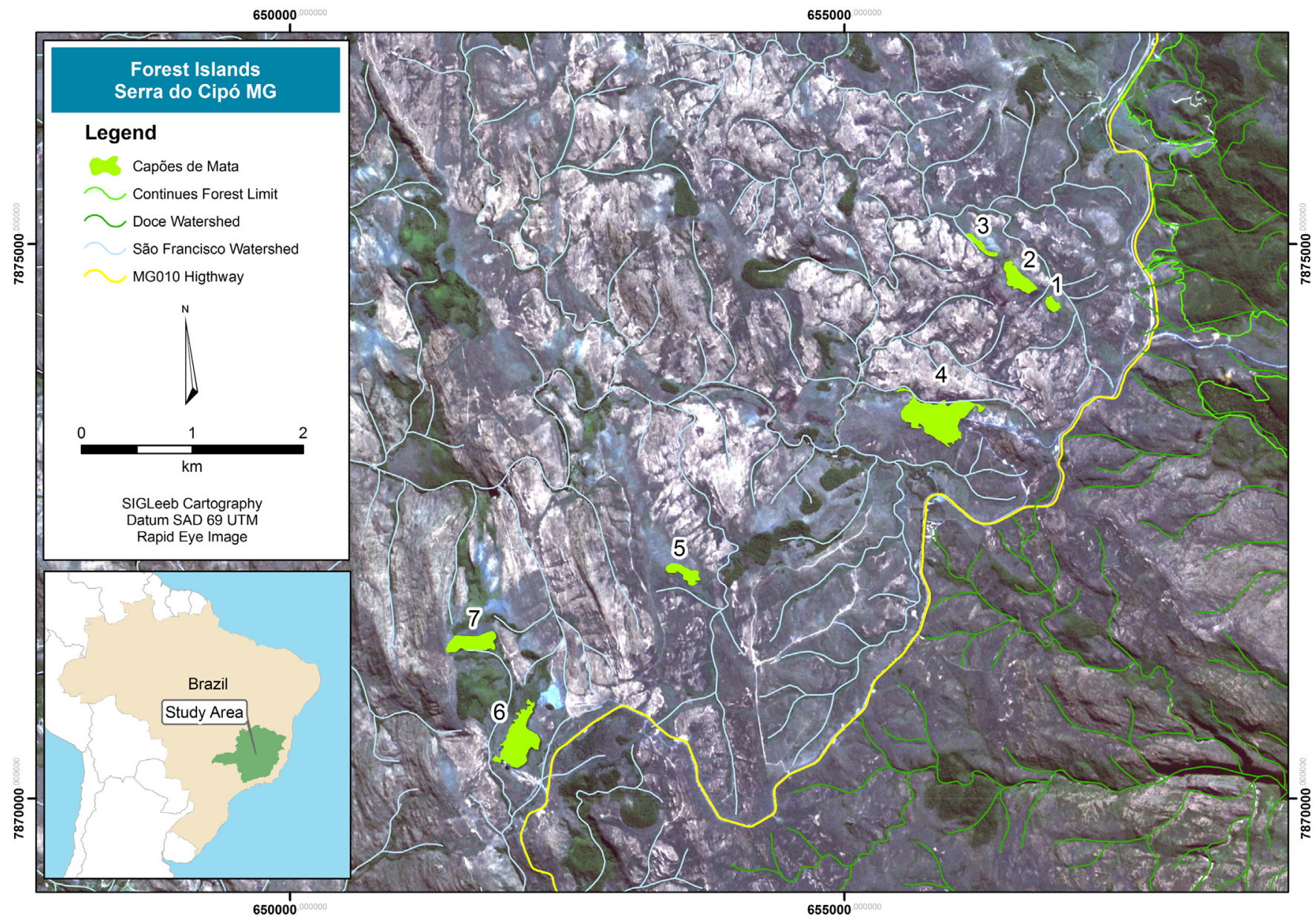

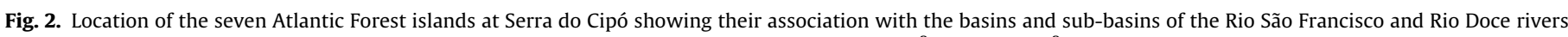

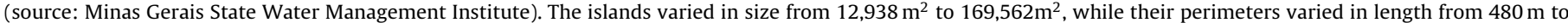
$2,836 \mathrm{~m}$.

Light Analyzer software, we calculated the effective leaf area index (LAI) was calculated and integrated along the zenith angle from 0 a $75^{\circ}$ (Welles and Norman, 1991).

\subsection{Data analyses}

A recent way of evaluating the response of functional traits of biological communities to habitat parameters was recently proposed by Dray et al. (2014), which combines two methods: the fourth-corner and RLQ(Dolédec et al., 1996; Legendre et al., 1997). We used these two methods to test the hypothesis of connection between the functional traits of the tree species and the environmental parameters. The two methods are complementary as RLQ uses simultaneously three matrices: matrix "R" (habitat parameters), matrix "L" (occurrence or abundance of species) and matrix "Q" (functional traits of species). The two methods cross the functional traits of the species with the environmental parameters mediated by the occurrence of the species at the sites. The complementarity of the two methods is that while RLQ synthesizes multivariate structures, fourth-corner tests the pair-to-pair significance of functional traits and habitat parameters (Dray et al., 2014). Therefore, these two methods combined can point to those functional traits that are related to specific habitat parameters and how these act synergistically. In the floristic matrix "L", rows corresponded to the areas (seventy $10 \times 10 \mathrm{~m}$ subplots), while columns corresponded to the 142 species sampled, with each cell being filled with the values with presence and absence data. In the functional matrix "Q", rows corresponded to the 142 tree species and columns to the seven plant functional attributes.

For the functional matrix, the mean values of height, basal area, leaf area and leaf herbivory (leaf damage caused by chewing herbivores) were used in addition to the abundance of individuals. The potential height of each species, as well as the number of ecoregions in which they occur, were obtained from Oliveira-Filho (2014) and BFG (2015). In the environmental matrix "R", rows corresponded to the 70 subplots, while columns corresponded to twelve environmental parameters. The environmental parameters were LAI and the following chemical and physical variables of the soil: $\mathrm{pH}, \mathrm{P}$, $\mathrm{K}, \mathrm{Ca}^{2+}+\mathrm{Mg}^{2+}, \mathrm{K} \mathrm{Al}^{3+}$, and $\mathrm{H}+\mathrm{Al}, \mathrm{Al}$ saturation, base saturation, total organic carbon, sand, and silt. Normality was achieved by means of logarithmic transformation, when necessary, to meet the assumptions of the tests. The fourth-corner analysis was first used to evaluate the significance of the correlation of species traits with each environmental parameter using the "combined" method of null models 2 and 4, as suggested by Dray and Legendre (2008). After this step, only biological traits that were significantly correlated with more than one environmental parameter were selected for the RLQ analysis. The best model to attend the goals of our study was not the most robust, but the more informative among those statistically significant. Only parameters which were not correlated with at least one trait were excluded of the model. The RLQ analysis aimed to find the combination of biological traits with maximum covariance with a given combination of habitat parameters (Dolédec et al., 1996). 
To perform RLQ a correspondence analysis was employed for the floristic matrix, while principal component analysis (PCA) was used for the functional and environmental matrices. In the functional PCA, species received relative weight corresponding to the frequency in which they occurred in the areas, and in the environmental PCA the areas received relative weight corresponding to their species richness (Dolédec et al., 1996; Dray and Dufour, 2007; Pavoine et al., 2011). Both analyses were performed in the $\mathrm{R}$ environment (R Development Core Team, 2012) with the package "ade4" and some functions provided by Pavoine et al. (2011).

\section{Results}

There was a strong connection between the functional traits of the 142 tree species distributed among 2008 individuals and the environmental parameters in the forest islands. The seven functional traits of the species tested by the fourth-corner analysis were significantly correlated with more than one environmental parameter (Fig. 3). Leaf herbivory (leaf damage caused by chewing insects) was positively related to the leaf cover index (LAI) and to base saturation, and negatively correlated to $\mathrm{Al}$ saturation, $\mathrm{Al}$ and $\mathrm{H}+\mathrm{Al}$. Leaf area was also positively related to LAI and percentage of silt in the soil, and negatively correlated to $\mathrm{Al}$ concentration, and potential acidity $(\mathrm{H}+\mathrm{Al})$. The number of ecoregions and the mean height of the trees were positively related to some indicators of soil fertility (i.e., base saturation, $\mathrm{Ca}+\mathrm{Mg}, \mathrm{K}$, and total organic carbon) and negatively correlated to $\mathrm{Al}$ saturation. On the other hand, potential height was positively related to the contents of $K, P$, percentage of organic carbon and percentage of organic sand, and negatively correlated to the percentage of silt. The mean basal area was negatively correlated to LAI, and positively correlated to indicators of soil fertility (i.e., $\mathrm{Ca}+\mathrm{Mg}$ and $\mathrm{K}$ ). The number of individuals was inversely correlated to mean tree height, negatively correlated to parameters associated with soil fertility (e.g., base saturation, $\mathrm{pH}$ and $\mathrm{Ca}+\mathrm{Mg}$ ) and positively correlated to Al saturation (Fig. 3).

The global association between species traits and habitat structure was strongly significant $(p=0.0001)$, according to the test based on the total co-inertia of the RLQ analysis (Monte Carlo with 50,000 permutations). Axis 1 of the RLQ explained $75.2 \%$ of the total variation. The positive side of this axis represented areas with higher LAI, higher aluminum saturation, and lower soil fertility, represented by low cation content, low base saturation and low percentage of organic carbon (Fig. 4a). The most important species shared similar attributes, with lower number of ecoregions and lower potential height (Fig. 5b). The positive side of this axis was represented by, among others, the species Geonoma schottiana (Arecaceae), Miconia paulensis (Melastomataceae), Tibouchina sellowiana (Melastomataceae), Solanum pseudoquina (Solanaceae) and Miconia brasiliensis (Melastomataceae) (Fig. 5a). The negative side of RLQ axis 1 represented environments with higher soil fertility (higher $\mathrm{Ca}+\mathrm{Mg}$, $\mathrm{K}$, organic carbon and base saturation contents) (Fig. 4a). The most important species here also shared similar attributes, such as a broader distribution among Brazilian ecoregions, and potential height (Fig. 4b), represented mainly by the species Apuleia leiocarpa (Fabaceae), Pera glabrata (Peraceae), Hieronyma alchorneoides (Phyllanthaceae), Nectandra membranacea (Lauraceae) and Richeria grandis (Phyllanthaceae) (Fig. 5a).

Axis 2 of the RLQ analysis explained $22.4 \%$ of the total variation. The positive side of this axis represented sites environments with soils with more aluminum toxicity (e.g. $\mathrm{Al}, \mathrm{H}+\mathrm{Al}$, and $\mathrm{Al}$ saturation), with higher concentrations of $P$ and organic carbon, and lower base saturation, $\mathrm{pH}$, LAI and $\mathrm{Ca}+\mathrm{Mg}$ (Fig. 4c). The most important species in these areas share similar traits such as high potential height and abundance of individuals, and with low leaf area and leaf herbivory (Fig. 4d). The positive side of the axis was represented by, among others, Cabralea canjerana (Meliaceae), Casearia decandra (Salicaceae), Protium spruceanum (Burseraceae), Sapium glandulosum (Euphorbiaceae) and Leucochloron incuriale (Fabaceae) (Fig. 5b). The negative side of axis 2 represented soil environments with high base saturation and $\mathrm{pH}$, as well as high leaf cover values (LAI) (Fig. 4c). The most important species in these areas shared similar attributes, such as higher values of leaf area and leaf herbivory (Fig. 4d). The negative side of this axis was represented by, among others, the species Cecropia pachystachya (Cecropiaceae), Piper gaudichaudianum (Piperaceae), Davilla elliptica (Dilleniaceae), Aegiphila verticillata (Lamiaceae) and Guatteria pogonopus (Annonaceae) (Fig. 5b).

\section{Discussion}

Our results demonstrated that species established on less fertile soils experienced lower rates of leaf damage, than species established on more fertile soils, which suffered higher rates of leaf damage. That is, leaf damage caused by chewing insects was significantly related to the canopy cover index and parameters associated with fertility (i.e. base saturation, $\mathrm{Al}$ saturation, $\mathrm{Al}$ and $\mathrm{H}+\mathrm{Al}$ ). Species such as Cecropia pachystachya, Piper gaudichaudianum, Davilla elliptica, Aegiphila verticillata and Guatteria pogonopus were associated with more fertile soils and were experienced higher herbivory, while species such as Cabralea canjerana, Casearia decandra, Protium spruceanum and Sapium glandulosum were associated with less fertile soils with higher concentrations of aluminum, and experienced less foliar damage from herbivorous insects. Several studies have shown that resource concentrationf is positively related to the activity of herbivorous insects (Coley et al., 1985; Endara and Coley 2011). For instance, in an experiment conducted in the Peruvian Amazon, Fine et al. (2004) demonstrated that when herbivores were excluded from areas with infertile soils, species possessing costly defenses against natural enemies were than in competitive disadvantages. Finally, there may also exist a relationship between the preference of some species we studied for soils with high Al concentration, Al-accumulating and reduced herbivory (Souza et al., 2014 and references therein). The existence of Al accumulating species on forest islands is an important characteristic to be investigated and that may explain in part the species composition of forest islands.

The results have also showed that leaf area was negatively related to the concentration of aluminum and potential acidity, which are strong indicators of soil fertility. In addition, leaf area was also positively related to the canopy coverage index. The most frequent species in areas with higher canopy cover (e.g. Cecropia pachystachya, Piper gaudichaudianum, Davilla elliptica, Aegiphila verticillata and Guatteria pogonopus) have the larger leaf areas, a strategy associated with maximizing light interception (Falster and Westoby, 2003). The leaf area of tree species plays an important evolutionary role in convergent adaptations, photosynthetic activity, carbon assimilation and water and energy balance, as well as light capture and ecological relationships, such as herbivory and organic matter decomposition (Freschet et al., 2011). The current literature points out to a decline in tree leaf area with a decrease in soil moisture and fertility (Dwyer et al., 2014), corroborating our findings. In infertile soils, species and individuals with smaller leaves are favored because of the slow vegetative growth under these conditions (McDonald et al., 2003). The increase in leaf area is directly associated with survival, nutrient retention and protection against desiccation (Fonseca et al., 2000). Small leaves are favored in environments with high solar incidence and low water availability, as the habitats holding forest islands in the present study, thereby 


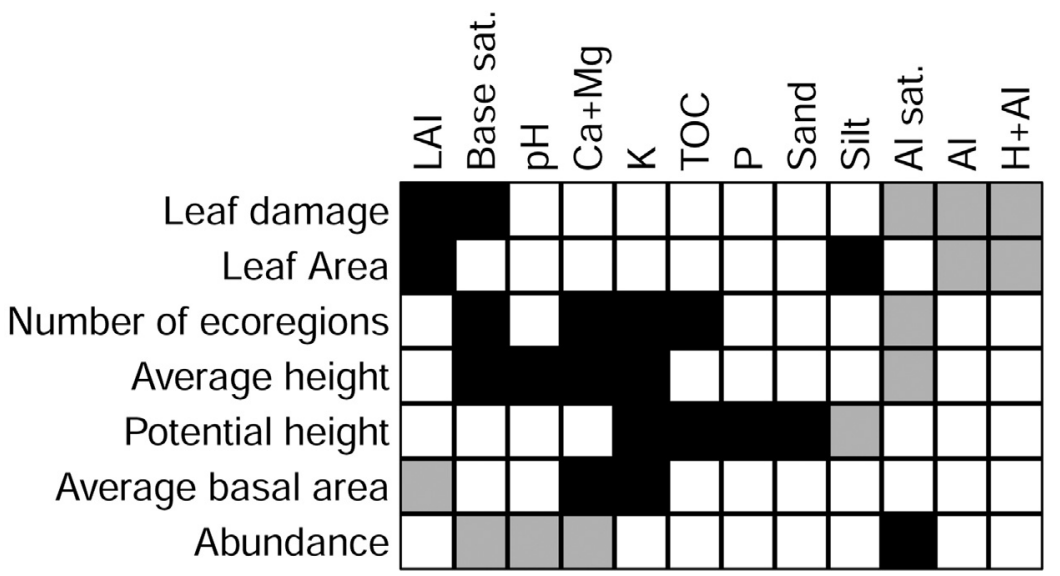

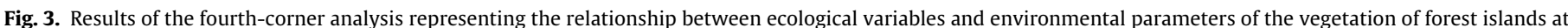

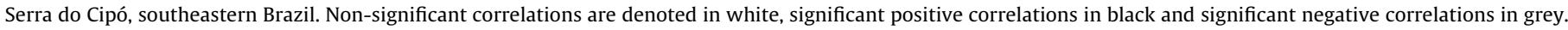
The level of significance was $\alpha=0.05$.

(a) LAI Al sat. Silt Al Sand $\mathrm{pH}$ $\mathrm{H}+\mathrm{Al}$ $P$ Base sat. TOC $\mathrm{K}$ $\mathrm{Ca}+\mathrm{Mg}$

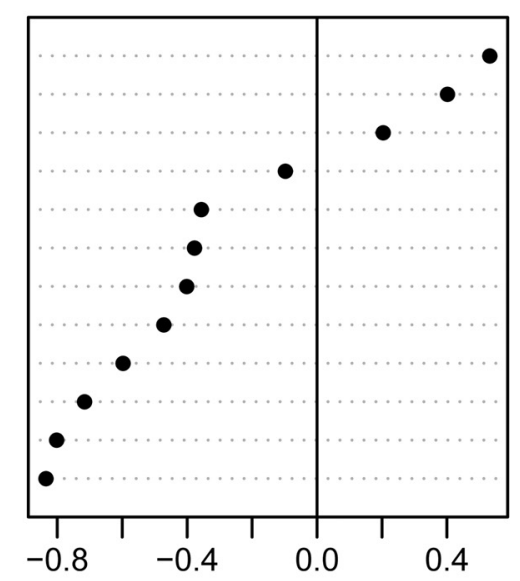

(b)

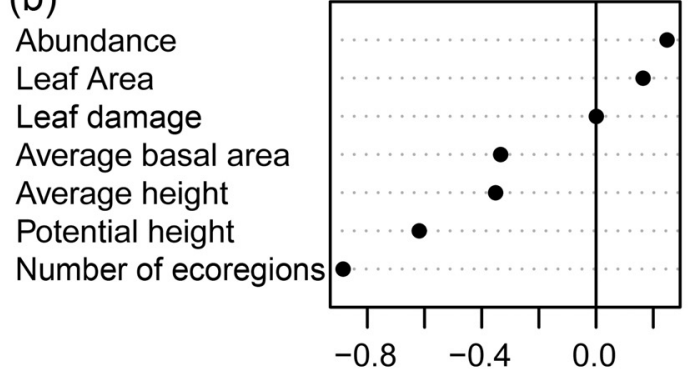

Correlation with RLQ axis 1 (75.18\%) (c)

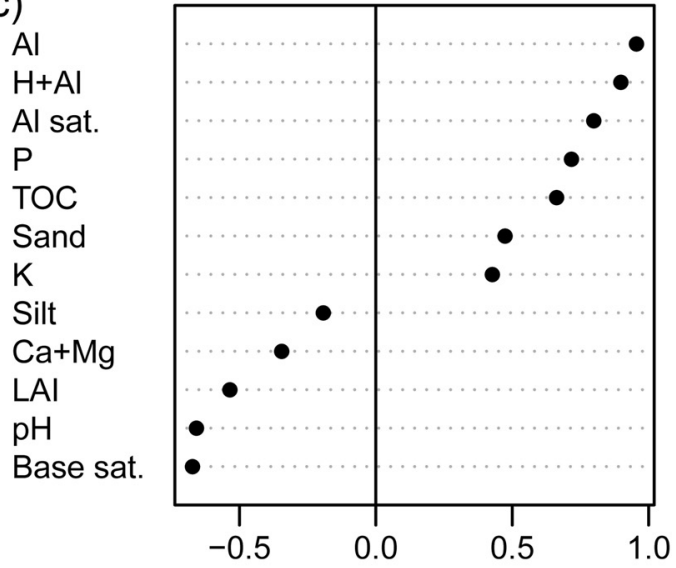

(d)

Potential height

Abundance

Number of ecoregions

Average basal area

Average height

Leaf damage

Leaf Area

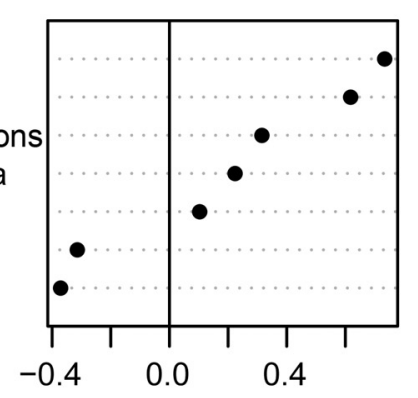

Correlation with RLQ axis 2 (22.35\%)

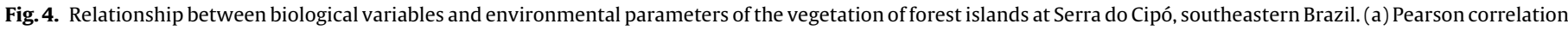

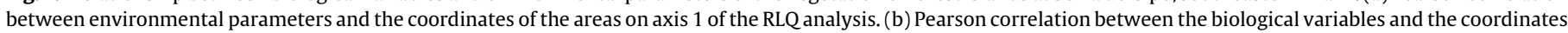

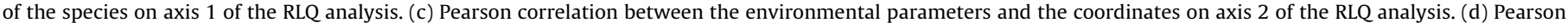
correlation between the biological variables and the coordinates on axis 2 of the RLQ.

maximizing the efficiency of photosynthetic activity (Wright et al., 2004; Poorter and Rozendaal 2008; Ordoñez et al., 2009).

We have also demonstrated that the more widely distributed species - those occurring in a greater number of Brazilian ecoregions - were sampled preferentially in more fertile soils, and with lower acidity and aluminum concentration. Areas with less fertile soils preferentially harbored species with more restricted distributions. In an extensive review, Coelho et al. (2016) demonstrated that the establishment and development of forest islands are strongly related to soil parameters, both chemical and physi- cal, which was corroborated by the results reported here. Species such as Apuleia leiocarpa, Pera glabrata, Hieronyma alchorneoides and Nectandra membranaceae, which are distributed widely among different Brazilian ecoregions, are connected to the parameters of soil fertility, while Cabralea canjerana, Casearia decandra, Protium spruceanum and Sapium glandulosum are more closely associated with the Atlantic Forest and comparatively less fertile soils - with lower nutrient levels, and with higher acidity and aluminum concentrations. Additional evidence suggest that soil parameters are directly related to species composition within the same plant for- 
(a)

Geonoma schottiana
Miconia paulensis
Tibouchina sellowiana
Solanum pseudoquina
Miconia brasiliensis
Guatteria australis
Myrceugenia rufescens
Vantanea compacta
Inga uruguensis
Roupala montana
Simarouba amara
Machaerium brasiliensis
Prunus myrtifolia
Cecropia pachystachya
Myrcia multiflora
Pogonophora schomburgkiana
Pouteria torta
Richeria grandis
Nectandra membranacea
Hieronyma alchorneoides
Pera glabrata
Apuleia leiocarpa

Apuleia leiocarpa

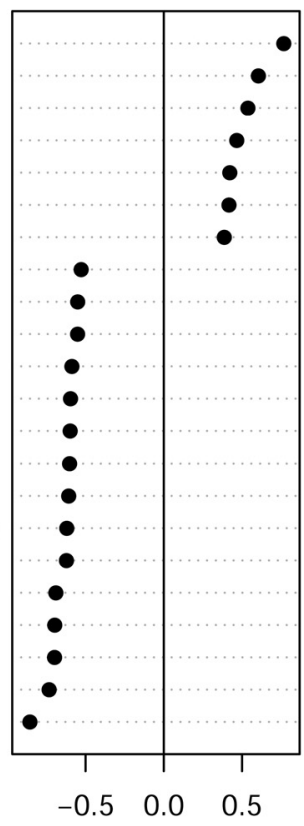

Species scores on RLQ axis 1 (78.18\%) (b)

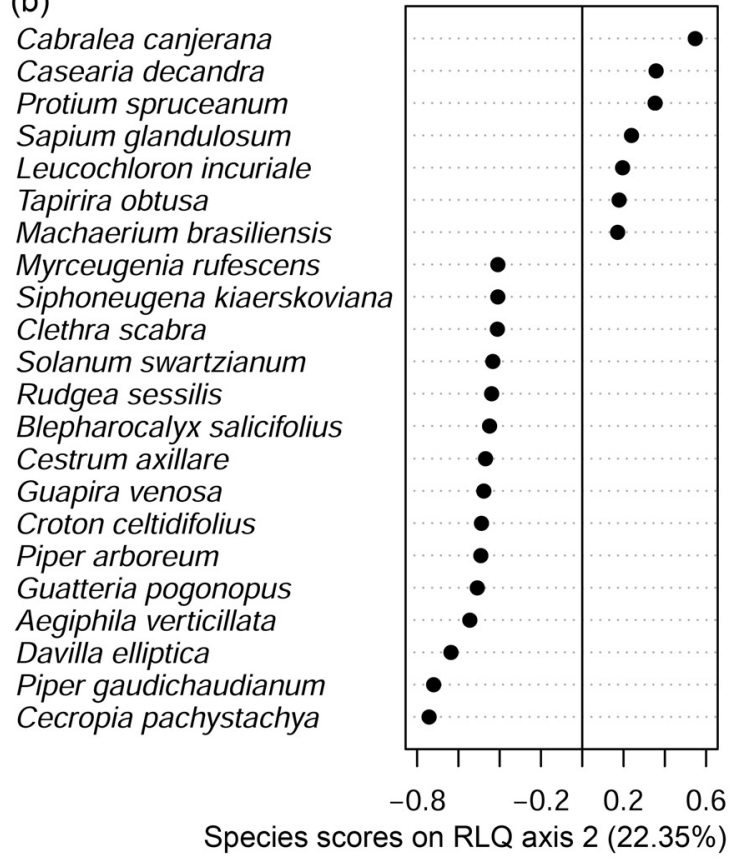

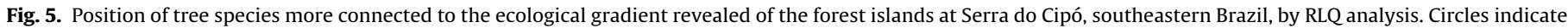
the values of the coordinates of each tree species on axis 1 (a) and axis 2 (b) of the RLQ analysis. See supplementary material for all species.

mation, with species responding to $\mathrm{pH}$ and $\mathrm{Al}^{3+}$ as well as other fertility indicators, revealing different competitive capacities under different soil conditions (Oliveira-Filho et al., 2001; Pinto et al., 2005; Sanchez et al., 2013). The influence of soil parameters is also associated with the occurrence of species among different physiognomies of the Atlantic Forest, some of which are classified as rare, while others are more generalist or common (Caiafa and Martins, 2010).

The mean height and basal area were related to soil fertility parameters (e.g., high concentration of base saturation, low aluminum concentration and lower acidity) of forest islands. There was a strong connection between soil parameters and the establishment of certain species. Potential height connected with the same environmental parameters (K, TOC, P, sand), showing that not only individuals but also largest species (e.g. Apuleia leiocarpa, Pera glabrata, hieronyma alchorneoides and Nectandra membranaceae) were established in more fertile soils. Studies have already demonstrated the strong influence of soil on vegetation structure associated with the Atlantic Forest (Budke et al., 2007; Pereira et al., 2007). Species with higher values of height and basal area are associated with greatest resource availability due to high metabolic demands and biomass accumulation (Van den Berg and Oliveira-Filho, 1999; Oliveira-Filho et al., 2001).

Species abundance across the islands was positively related to acidic, aluminum rich and less fertile soils. Soils of low fertility limit growth and the accumulation of biomass by trees, which can lead to low values of functional traits as mean height, basal area and an increase in density, that is, greater abundance of trees with lower values of height and basal area (Guariguata and Ostertag, 2001; Higuchi et al., 2008). In addition, forest islands are located on mountaintops and are exposed to strong gusts of wind, which causes frequent tree falls (Coelho et al., 2016). In a small forest, such as the islands studied here, tree falls alter the successional stage of the vegetation (Connell, 1978; Budke et al., 2010). Succession is likely a strong driver for the patterns of connection between species and the environmental parameters, since it affects the composition and structure of the tree community as well as the formation and con- dition of the soil, leading to similar early successional conditions (Freschet et al., 2011).

The present study showed the strong connection between species traits and environmental parameters. Islands with more fertile, less acidic soils with higher canopy cover exhibited species with higher structural values (i.e., height and basal area), wider distribution among Brazilian ecoregions, higher rates of leaf herbivory and fewer individuals. On the other hand, islands with less fertile, more acidic soils, with high levels of aluminum and lower canopy cover presented species with lower structural values, more restricted distributions among Brazilian ecoregions and lower rates of leaf damage from chewing insects. Although the physical parameters of the soil played a more important role than the chemical properties for the establishment of forest islands, the results reported here point out to chemical indicators of soil fertility as a relevant environmental promoter for tree species, allowing not only the establishment but alto the development, and thus as key factors determining vegetation composition.

The understanding of how naturally isolated communities are structured, based on functional traits and environmental parameters can be applied to understand human-derived fragmented landscapes (Laurance, 2008). The present study has shown the role of local environmental parameters strongly influencing the functional trait composition in tree communities also indicating that habitat heterogeneity is essential in structuring tree communities in this archipelago of natural islands of Atlantic rainforest (Cadotte and Tucker, 2017). The connection of local environmental parameters with the species functional traits can help predict the effects of anthropogenic and natural impacts, such as fire (see Coelho et al., 2018), and support the development of effective conservation strategies.

\section{Acknowledgments}

This study was in partial fulfillment of the Ph.D. requirements of M.S. Coelho. We thank CNPq, CAPES, and FAPEMIG for financial support and Reserva Vellozia for logistical support. M.S. Coelho 
receives a PDJ fellowship and LPS Morellato and GW Fernandes a Research Productivity fellowship from CNPq, and final writing and analysis were conducted in the Phenology Lab supported by FAPESP and CNPq. We are also grateful to Heron Hilário and Lucas Perillo for providing high quality photos to better illustrate the forest islands of the Espinhaço Range. We thank the anonymous reviewers and the editor FAO Silveira for their careful reading of our manuscript and their many insightful comments and suggestions.

\section{Appendix A. Supplementary data}

Supplementary data associated with this article can be found, in the online version, at http://dx.doi.org/10.1016/j.flora.2017.04. 003.

\section{References}

APG IV, 2016. An update of the angiosperm phylogeny group classification for the orders and families of flowering plants: APG IV. Bot. J. Linn. Soc. 181, 1-120.

Ackerly, D.D., Cornwell, W.K., 2007. A trait-based approach to community assembly: partitioning of species trait values into within- and among-community components. Ecol. Lett. 10, 135-145.

Alvares, C.A., Stape, J.L., Sentelhas, P.C., Moraes, J.L.M., Sparovek, G., 2013. Köppen's climate classification map for Brazil. Meteorol. Z. 22, 711-728.

Alvarez, V.H.V., Novais, R.F., Barros, N.F., Cantarutti, R.B., Lopes, A.S., 1999. Interpretação dos resultados das análises de solos. In: Ribeiro, A.C., Guimarães, P.T.G., Alvarez, V.H.V. (Eds.), Recomendação para o uso de corretivos e fertilizantes em Minas Gerais. Comissão de Fertilidade do Solo do Estado de Minas Gerais, Viçosa, pp. 25-32.

BFG, 2015. Growing knowledge: an overview of seed plant diversity in Brazil. Rodriguésia 66, 1085-1113.

Binkley, D., Vitousek, P., 1989. Soil nutrient availability. In: Pearcy, R.W., Ehleringer, J.R., Mooner, H.A., Rundel, P.W. (Eds.), Plant Physiological Ecology. Field methods and instrumentation. Chapman and Hall, Amsterdam, pp. 75-96.

Bond, W.J., Keeley, J.E., 2005. Fire as a global herbivore: the ecology and evolution of flammable ecosystems. Trends Ecol. Evol. 20, 387-394.

Bond, W.J., 2008. What limits trees in $\mathrm{C}_{4}$ grasslands and savannas? Annu. Rev. Ecol. Evol. Syst. 39, 641-659.

Bond, W.J., 2010. Do nutrient-poor soils inhibit development of forests? A nutrient stock analysis. Plant Soil 334, 47-60.

Budke, J.C., Jarenkow, J.A., Oliveira-Filho, A.T., 2007. Relationships between tree component structure, topography and soils of a riverside forest, Rio Botucaraí, Southern Brazil. Plant Ecol. 189, 187-200.

Budke, J.C., Jarenlow, J.A., Oliveira-Filho, A.T., 2010. Intermediary disturbance increases tree diversity in riverine forest of Southern Brazil. Biodivers Conserv 19, 2371-2387.

Cadotte, M.W., Tucker, C.M., 2017. Should environmental filtering be abandoned? Tree (in press)

Caiafa, A.N., Martins, F.R., 2010. Forms of rarity of tree species in the Southern Brazilian Atlantic rainforest. Biodivers. Conserv. 19, 2597-2618.

Cierjacks, A., Iglesias, J.E., Wesche, K., Hensen, I., 2007. Impact of sowing, canopy cover and litter on seedling of two Polylepis species at upper tree llines in central Ecuador. J. Trop. Ecol. 23, 309-318.

Coelho, M.S., Fernandes, G.W., Pacheco, P., Diniz, V., Meireles, A., Santos, R.M., Carvalho, F.C., Negreiros, D., 2016. Archipelago of montane forests surrounded by rupestrian grasslands: new insights and perspectives. In: Fernandes, G.W. (Ed.), Ecology and Conservation of Mountain-top Grasslands in Brazil. Springer, New York, pp. 129-153.

Coelho, M.S., Neves, F.S., Perillo, L.N., Morellato, P., Fernandes, G.W., 2018. Forest archipelagos: a natural model of metacommunity under the threat of fire. Flora 238, 244-249.

Coley, P.D., Bryant, J.P., Chapin III, F.S., 1985. Resource availability and plant antiherbivore defence. Science 230, 895-899.

Connell, J.H., 1978. Diversity in tropical rain forest and coral reefs. Science 199 1302-1310.

Dick, R.P., Thomas, D.R., Halvorson, J.J., 1996. Standardized methods, sampling and sample pretreatment. In: Doran, J.W., Jones, A.J. (Eds.), Methods for Assessing Soil Quality. SSSA Special Publication, Madison, pp. 107-121.

Dolédec, S., Chessel, D., ter Braak, C.J.F., Champely, S., 1996. Matching species traits to envinmental variables: a new three-table ordination method. Environ. Ecol. Stat. 3, 143-166.

Dray, S., Dufour, A.B., 2007. The ad4 package: implementing the duality diagram for ecologists. J. Stat. Softw. 22, 1-20.

Dray, S., Legendre, P., 2008. Testing the species traits-environment relationships: the fourth-corner problem revisited. Ecology 89, 3400-3412.

Dray, S., Choler, P., Dolédec, S., Peres-Neto, P.R., Thuiller, W., Pavoine, S., ter Braak, C.J.F., 2014. Combining the fourth-corner and the RLQ methods for assessing trait responses to environmental variation. Ecology 95, 14-21.

Dullinger, S., Dirnböck, T., Grabherr Grabherr, G., 2004. Modelling climate change-driven treeline shifts: relative effects of temperature increase, dispersal and invisibility. J. Ecol. 92, 241-252.
Dwyer, J.M., Hobbs, R.J., Mayfield, M.M., 2014. Specific leaf area responses to environmental gradients through space and time. Ecology 95, 399-410. EMBRAPA -Empresa Brasileira de Pesquisa Agropecuária, 1999. Manual de análises químicas de solos, plantas e fertilizantes. Embrapa Solos, Brasília.

Endara, M.-J., Coley, P.D., 2011. The resource availability hypothesis revisited: a meta-analysis. Funct. Ecol. 25, 389-398.

Englund, G., Johansson, F., Olofsson, P., Salonsaari, J., Ohman, J., 2009. Predation leads to assembly rules in fragmented fish communities. Ecol. Lett. 12 663-671.

Falster, D.S., Westoby, M., 2003. Leaf size and angle vary widely across species: what consequences for light interception? New Phytol. 158, 509-525.

Fernandes, G.W., Almeida, H.A., Nunes, C.A., Xavier, J.H.A., Cobb, N.S., Carneiro, M.A.A., Cornelissen, T., Neves, F.S., Ribeiro, S.P., Nunes, Y.R.F., Pires, A.C.V., Beirão, M.V., 2016. Cerrado to rupestrian grasslands: patterns of species distribution and the forces shaping them along an altitudinal gradient. In: Fernandes, G.W. (Ed.), Ecology and Conservation of Mountain-top Grasslands in Brazil. Springer, New York, pp. 345-377.

Fine, P.V.A., Mesones, I., Coley, P.D., 2004. Herbivores promote habitat specialization by trees in Amazonian forests. Science 305, 663-665.

Fonseca, C.R., Overton, J.M., Collins, B., 2000. Shifts in trait-combinations along rainfall and phosphorus gradients. J. Ecol. 88, 964-977.

Frazer, G.W., Canham, C.D., Lertzman, K.P., 1999. Gap Light Analyser (GLA): Imaging Software to Extract Canopy Structure and Gal Light Transmission Indices from True Colour Fisheye Photographs, Users, Manual and Program Documentation. Simon Fraser University, Millbrook.

Freschet, G.T., Dias, A.T.C., Ackerly, D.D., Aerts, R., van Bodegom, P.M., Cornwell, W.K., Dong, M., Kurokawa, H., Liu, G., Onipchenko, V.G., Ordoñez, J.C., Peltzer D.A., Richardson, S.J., Shidakov, I.I., Soudzilovskaia, N.A., Tao, J., Cornelissen, J.H.C., 2011. Global to community scale differences in the prevalence of convergent over divergent leaf trait distributions in plant assemblages. Global Ecol. Biogeogr. 20, 755-765.

Gotelli, N.J., McCabe, D.J., 2002. Species co-occurrence: a meta-analysis of JM Diamond‘s assembly rule model. Ecology 83, 2091-2096.

Grime, J.P., Pierce, S., 2012. The Evolutionary Strategies That Shape Ecosystems. Wiley-Blackwell, Chichester.

Guariguata, M.R., Ostertag, R., 2001. Neotropical secondary forest succession: changes in structural and functional characteristics. For. Ecol. Manag. 148, $185-206$.

Halladay, K., Malhi, Y., New, M., 2012. Cloud frequency climatology at the Andes/Amazon transition: 1: Seasonal and diurnal cycles. J. Geophys. Res. Atmos. 117, D23102.

Higuchi, P., Oliveira-Filho, A.T., Bebber, D.P., Brown, N.D., Silva, A.C., Machado, E.L.M., 2008. Spatial and temporal patterns of tree community dynamics in a tropical forest along 19-year period. Plant Ecol. 199, 125-135.

Jamoneau, A., Closset-Kopp, D., Decocq, G., 2011. Fragmentation alters beta-diversity patterns of habitat specialist within forest metacommunities. Ecography 35, 124-133.

Jobbágy, E.G., Jackson, R.B., 2000. Global controls of forest line elevation in the Northern and Southern Hemispheres. Global Ecol. Biogeogr. 9, 253-268.

Körner, C., Paulsen, J., 2004. A world-wide study of high altitude treeline temperatures. J. Biogeogr. 31, 713-732.

Körner, C., 1998. A re-assessment of high elevation treeline positions and their explanation. Oecologia 115, 445-459.

Körner, C., 2012. Alpine Treelines. Functional Ecology of the Global High Elevation Tree Limits. Springer, Switzerland.

Kolbek, J., Alves, R.J.V., 2008. Impacts of cattle, fire and wind in rocky savannas, southeastern Brazil. Acta Univ. Carol. Environ. 22, 111-130.

Kraft, N.J.B., Godoy, O., Levine, J.M., 2015. Plant functional traits and the multidimensional nature of species coexistence. PNAS 112, 797-802

Lasky, J.R., Sun, I.-F., Su, S.-H., Chen, Z.-S., 2013. Trait-mediated effects of environmental filtering on tree community dynamics. J. Ecol. 101, 722-733.

Laurance, W.F., 2008. Theory meets reality: how habitat fragmentation research has transcended island biogeographic theory. Biol. Conserv. 141, 1731-1744.

Lavorel, S., Garnier, E., 2002. Predicting changes in community composition and ecosystem functioning from plant traits: revisiting the Holy Grail. Funct. Ecol. $16,545-556$.

Lebrija-Trejos, E., Pérez-Gárcia, E.A., Meave, J.A., Bongers, F., Poorter, L., 2010 Functional traits and environmental filtering drive community assembly in a species-rich tropical system. Ecology 91, 386-398.

Legendre, P., Galzin, R., Harmelin-Vivien, M.L., 1997. Relating behavior to habitat: solutions to the fourth-corner problem. Ecology 78, 547-562.

Madeira, J.A., Fernandes, G.W., 1999. Reprodutive phenology of sympatric taxa of Chamaecrista (Leguminosae) in Serra do Cipó, Brazil. J. Trop. Ecol. 15, 463-479.

Madeira, J.A., Ribeiro, K.T., Oliveira, M.J.R., Nascimento, J.S., Paiva, C.L., 2008. Distribuiça o espacial do esforço de pesquisa bioloígica na Serra do Cipoí, Minas Gerais: subsiídios ao manejo das unidades de conservaça o da regia o. Megadiversidade 4, 255-269.

McDonald, P.G., Fonseca, C.R., Overton, J.M., Westoby, M., 2003. Leaf-size divergence along rainfall and soil-nutrient gradients: is the method of size reduction common among clades? Funct. Ecol. 17, 50-57.

Mueller-Dombois, D., Elemberg, H., 1974. Aims and Methods of Vegetation Ecology. Willey and Sons, New York.

Negreiros, D., Le Stradic, S., Fernandes, G.W., Rennó, H.C., 2014. CSR analysis of plant functional types in highly diverse tropical grasslands of harsh environments. Plant Ecol. 215, 379-388. 
Oliveira-Filho, A.T., Curi, N., Vilela, E.A., Carvalho, D.A., 2001. Variation in tree community composition and structure with changes in soil properties within a fragmente of semideciduous forest in South-eastern Brazil. Edinb J. Bot. 58, 139-158.

Oliveira-Filho, A.T., 2014. NeoTropTree, Flora arbórea da Região Neotropical: Um banco de dados envolvendo biogeografia, diversidade e conservação. Universidade Federal de Minas Gerais, http://www.icb.ufmg.br/treeatlan/. (Accessed 03 November 2016).

Ordoñez, J.C., van Bodegom, P.M., Witte, J.-P.M., Wright, I.J., Reich, P.B., Aerts, R., 2009. A global study of relationships between leaf traits, climate and soil measures of nutrient fertility. Global Ecol. Biogeogr. 18, 137-149.

Paine, C.E.T., Baraloto, C., Chave, J., He írault, B., 2011. Functional traits of individual trees reveal ecological constraints on community assembly in tropical rain forests. Oikos 120, 720-727.

Pavoine, S., Vela, E., Gachet, S., de Bélair, G., Bonsall, M.B., 2011. Linking patterns in phylogeny, traits, abiotic variables and space: a novel approach to linking environmental filtering and plant community assembly. J. Ecol. 99, 165-175.

Pereira, J.A.A., Oliveira-Filho, A.T., Lemos Filho, J.P., 2007. Environmental heterogeneity and disturbance by human control much of the tree species diversity of fragments of tropical montane seasonal forests in SE Brazil. Biodivers Conserv 16, 1761-1784.

Pereira, G.C.N., Coelho, M.S., Beirão, M.V., Braga, R.F., Fernandes, G.W., 2017. Diversity of fruit-feeding butterflies in a mountain archipelago of rainforest. PLoS One (in press).

Pinto, J.R.R., Oliveira-Filho, A.T., Hay, J.D.V., 2005. Influence of soil and topography on the composition of a tree community in a central Brazilian valley forest. Edinb J. Bot. 62, 69-90.

R Development Core Team, R., 2012. R: a Language and Environmentfor Statistical Computing. Version 2.15.1. R Foundation for Statistical Computing, Vienna, http://www.rproject.org. (Accessed 05 November 2016).

Rehm, E.M., Feeley, K.J., 2013. Forest patches and the upward migration of timberline in the southern Peruvian Andes. For. Ecol. Manag. 305, 204-211.

Rehm, E.M., Feeley, K.J., 2015. The inability of tropical cloud forest species to invade grasslands above treeline climate change: potential explanations and consequences. Ecography 38, 1167-1175.

Safford, H.D., 2007. Brazilian Páramos IV: Phytogeography of the campos de altitude. J. Biogeogr. 34, 1701-1722.

Sanchez, M., Pedroni, F., Eisenlohr, P.V., Oliveira-Filho, A.T., 2013. Changes in tree community composition and structure of Atlantic rain forest on a slope of the Serra do Mar range, southeastern Brazil, from near sea level to $1000 \mathrm{~m}$ of altitude. Flora 208, 184-196.
Schaefer, C.E., Cândido, H.G., Corrêa, G.R., Nunes, J.A., Arruda, D.M., 2016. Soils associated with rupestrian grasslands. In: Fernandes, G.W. (Ed.), Ecology and Conservation of mountain-top grasslands in Brazil. Springer, New York, pp. 55-69.

Silveira, F.A.O., Negreiros, D., Barbosa, N.P.U., Buisson, E., Carmo, F.F., Carstensen, D.W., faConceição, A.A., Cornelissen, T.G., Echternacht, L., Fernandes, G.W., Garcia, Q.S., Guerra, T.J., Jacobi, C.M., Lemos-Filho, J.P., Le Stradic, S., Morellato, L.P.C., Neves, F.S., Oliveira, R.S., Schaefer, C.E., Viana, P.L., Lambers, H., 2016. Ecology and evolution of plant diversity in the endangered campo rupestre: a neglected conservation priority. Plant Soil 403, 129-152.

Southwood, T.R.E., 1988. Tactics, strategies and templets. Oikos 52, 3-18.

Souza, M.C., Rossato, D.R., Cook, G.D., Fujinuma, R., Menzies, N.W., Morellato, L.P.C., Habermann, G., 2014. Mineral nutrition and specific leaf area of plants under contrasting long-term fire frequencies: a case study in a mesic savanna in Australia. Trees 30, 329-335.

Streher, A.S., Sobreiro, J.F.F., Morellato, L.P.C., Silva, T.S.F., 2017. Land surface phenology in the tropics: the role of climate and topography in a snow-free moutain. Ecosystems, http://dx.doi.org/10.1007/s10021-017-0123-2 (in press).

Van den Berg, E., Oliveira-Filho, A.T., 1999. Spatial partitioning among tree species within an área of tropical montane gallery forest in South-eastern Brazil. Flora 194, 249-266.

Veldman, J.W., Buisson, E., Durigan, G., Fernandes, G.W., Stradic, S.L., Mahy, G., Negreiros, D., Overbeck, G., Veldman, R.G., Zaloumis, N.P., Putz, F.E., Bond, W.J., 2015. Toward an old-growth concept for grasslands, savannas, and woodlands. Front. Ecol. Environ. 13, 154-162.

Violle, C., Navas, M.-L., Vile, D., Kazakou, E., Fortunel, C., Hummel, I., Garnier, E., 2007. Let the concept of trait be functional! Oikos 116, 882-892.

Welles, J.M., Norman, J.M., 1991. Instrument for indirect measurement of canopy architecture. Agron. J. 83, 818-825.

Wright, I.J., Reich, P.B., Westoby, M., Ackerly, D.D., Baruch, Z., Bongers, F., Cavender-Bares, J., Chapin, T., Cornelissen, J.H.C., Diemer, M., Flexas, J., Garnier, E., Groom, P.K., Gulias, J., Hikosaka, K., Lamont, B.B., Lee, T., Lee, W., Lusk, C., Midgley, J.J., Navas, M.L., Niinemets, Ü., Oleksyn, J., Osada, N., Poorter, H., Poot, P., Prior, L., Pyankov, V.I., Roumet, C., Thomas, S.C., Tjoelker, M.G., Veneklaas, E.J., Villar, R., 2004. The worldwide leaf economics spectrum. Nature 428, 821-827.

de Bello, F., Lavorel, S., Díaz, S., Harrington, R., Cornelissen, J.H.C., Bardgett, R.D., Berg, M.P., Cipriotti, P., Feld, C.K., Hering, D., 2010. Towards an assessment of multiple ecosystem processes and services via functional traits. Biodivers. Conserv. 19, 2873-2893. 